\title{
Isolation of Uncultured Bacteria from Antarctica Using Long Incubation Periods and Low Nutritional Media
}

\author{
Andre A. Pulschen ${ }^{1}$, Amanda G. Bendia ${ }^{2}$, Ashwana D. Fricker ${ }^{1}$, Vivian H. Pellizari², \\ Douglas Galante ${ }^{3}$ and Fabio Rodrigues ${ }^{*}$. \\ 'Instituto de Química, Universidade de São Paulo, Butantã, Brazil, ${ }^{2}$ Departamento de Oceanografia Biológica, Instituto \\ Oceanográfico, Universidade de São Paulo, Butantã, Brazil, ${ }^{3}$ Laboratório Nacional de Luz Síncrotron, Centro Nacional de \\ Pesquisa em Energia e Materiais, Campinas, Brazil, ' ${ }^{4}$ Departamento de Química Fundamental, Instituto de Química, \\ Universidade de São Paulo, Butantã, Brazil
}

OPEN ACCESS

Edited by:

Brian D. Lanoil,

University of Alberta, Canada

Reviewed by:

Michael T. Madigan,

Southern Illinois University Carbondale, United States

Lyle Whyte,

McGill University, Canada

${ }^{*}$ Correspondence: Fabio Rodrigues farod@iq.usp.br

Specialty section: This article was submitted to

Extreme Microbiology, a section of the journal

Frontiers in Microbiology

Received: 12 March 2017 Accepted: 03 July 2017

Published: 14 July 2017

Citation:

Pulschen AA, Bendia AG, Fricker $A D$, Pellizari VH, Galante $D$ and Rodrigues F (2017) Isolation of Uncultured Bacteria from Antarctica Using Long Incubation Periods and Low Nutritional Media.

Front. Microbiol. 8:1346.

doi: 10.3389/fmicb.2017.01346
Uncultured microorganisms comprise most of the microbial diversity existing on our planet. Despite advances in environmental sequencing and single-cell genomics, indepth studies about bacterial metabolism and screening of novel bioproducts can only be assessed by culturing microbes in the laboratory. Here we report uncultured, or recalcitrant, microorganisms from an Antarctic soil sample, using relatively simple methods: oligotrophic media, extended incubation periods, observation under stereo microscopy, and selection of slow-growing bacteria. We managed to isolate several rare microorganisms belonging to infrequently isolated or recently described genera, for example Lapillicoccus, Flavitalea, Quadrisphaera, Motilibacter, and Polymorphobacter. Additionally, we obtained isolates presenting $16 \mathrm{~S}$ rRNA sequence similarity ranging from 92.08 to $94.46 \%$ with any other known cultured species, including two distinct isolates from the class Thermoleophilia, that although common in Antarctic soils (as identified by metagenomics), was never reported to be isolated from such samples. Our data indicates that simple methods are still useful for cultivating recalcitrant microorganisms, even when dealing with samples from extreme environments.

Keywords: uncultured, Antarctica, Solirubrobacterales, Thermoleophilia, slow-growing bacteria

\section{INTRODUCTION}

Most environmental microorganisms are still classified as uncultivable (Hug et al., 2016), or using the best definition, "yet-to-be cultivable," considering that all organisms should be able to grow and divide, and therefore, capable of growing under the proper conditions (Lewis et al., 2010; Vartoukian et al., 2010; Stewart, 2012).

Reasons for failing to grow most of the existing microorganisms in the laboratory vary. Some are simple, for example failing to supplement the correct nutrients (Kopke et al., 2005), using the wrong $\mathrm{pH}$, insufficient incubation periods (Janssen et al., 2002; Davis et al., 2011), or the use of extremely rich-media (which favors fast growing cells, that can overgrow slower microorganisms). Some are more complex, such as the need for specific growth signals (Bruns et al., 2002; Nichols et al., 2008), dependence on other microorganisms (D’Onofrio et al., 2010; He et al., 2015), or development as microcolonies (Davis et al., 2011).

Many reasons justify the interest in growing "uncultivable" organisms. Features such as determination of growth preferences, consumption or production of environmental metabolites 
(involved in nutrient cycling), physiological characteristics (cell size, morphology, pigmentation, motility, etc), and virulence profiles can only be properly studied by growing cells under laboratory conditions (Wade, 2002; Vartoukian et al., 2010; Stewart, 2012; Baker et al., 2015). Furthermore, growth of recalcitrant microbes has potential for biotechnological applications (Newman, 2016), for example the recently discovered bacterial species capable of degrading the environmental pollutant Polyethylene terephthalate (Yoshida et al., 2016) or the discovery of a novel antibiotic class, teixobactin, produced by a bacterium from a previously undescribed genus (Ling et al., 2015). Finally, features like resistance to environmental challenges, such as radiation, desiccation, extremely low or high temperatures also requires microbial isolation to be proper studied. Such investigations are important not only to improve our knowledge toward microbial physiology, but also to improve our knowledge about the limits of life, a topic that is of great interest for Astrobiology (Rothschild and Mancinelli, 2001; Mykytczuk et al., 2013; Pulschen et al., 2015; Paulino-Lima et al., 2016).

In order to assess and grow recalcitrant microorganisms, several technologies and methods have been developed. One of the most well-known techniques relies in using diffusion chambers (Kaeberlein, 2002; Ferrari et al., 2005), which allow the passage of nutrients and metabolites from the environment to the trapped microorganisms inside the chamber, achieving special requirements for the growth of certain cells. The iCHIP method (isolating chip) is a similar technique that optimizes the principles of diffusion chambers and it has already been used to isolate several novel bacteria (Nichols et al., 2010; Ling et al., 2015). Whole-genome sequencing can be used to develop isolation strategies based on the metabolic information existing in the genomic DNA (Tyson et al., 2005; Gtari et al., 2015; Wurch et al., 2016). Metatranscriptomic analysis has also been used to direct culturing of recalcitrant bacteria (Bomar et al., 2011). However, many of such techniques are time-consuming and/or imply a high cost. Some other techniques for retrieving hardto-culture microbes are much simpler, such as the choice of a different solidifying agent (Tamaki et al., 2009), longer incubation periods, growth in low nutrient media (Janssen et al., 2002; Sait et al., 2002; Davis et al., 2005), and separate preparation of media components (Tanaka et al., 2014). Most of the earth's biosphere (over $80 \%$ ) remains permanently cold, with temperatures below $5^{\circ} \mathrm{C}$ (Rodrigues and Tiedje, 2008; Cavicchioli et al., 2011; De Maayer et al., 2014). Studies with cold adapted microorganism are important due to their biotechnological potential (Cavicchioli et al., 2011), for improving our knowledge of how life thrives at low temperatures, and our understanding of how they impact global chemical cycles (Dedysh, 2011; De Maayer et al., 2014). Among such cold-environments, Antarctica stands out as the largest desert in the world, an environment with potential to render microbes that can vastly improve our knowledge of how life thrives in such harsh conditions and that can be considered a good analog to extraterrestrial environments, like Mars (Musilova et al., 2015; Goordial et al., 2016).

Here we report the isolation of uncultured microorganisms from a soil sample from Antarctica using a combination of simple techniques (Janssen et al., 2002; Sait et al., 2002; Davis et al., 2005; Tamaki et al., 2009; George et al., 2011; Tanaka et al., 2014). Slow growing bacteria were selected on diluted Nutrient Broth media solidified with Gellan gum after extended incubation periods (15 weeks) at a low temperature $\left(12^{\circ} \mathrm{C}\right)$. Bacterial colonies on the isolation plates were observed under a stereo microscope, and colonies that appeared only after 4 weeks of incubation were selected, to obtain only slow-growing bacteria. Colonies were chosen based on their morphological characteristics and picking similar colonies that developed on the plates at the same time was avoided.

\section{MATERIALS AND METHODS}

\section{Sample Collection}

Samples were collected on December 29, 2014, at Hennequin Point, Admiralty Bay, King George Island, Antarctica (Figure 1) during the XXXIII Brazilian Antarctic Operation (2014/2015). Specific coordinates from the sampling site are $62^{\circ} 07.112^{\prime} \mathrm{S}$, $58^{\circ} 23.199^{\prime} \mathrm{W}, 155 \mathrm{~m}$ altitude. The temperature during the sample collecting was around $0^{\circ} \mathrm{C}$. Between 20 and 50 grams of soil was collected using flame-sterilized tools, stored in sterile tubes sealed in "Whirl-Pak" bags (Nasco, United States), and kept at $-20^{\circ} \mathrm{C}$ during transportation, until the arrival in the laboratory in Brazil, where it was maintained at $-20^{\circ} \mathrm{C}$ until isolation.

\section{Isolation Procedures}

All contamination-sensitive procedures were performed inside a laminar flow hood. For isolation of the microorganisms, $2 \mathrm{~g}$ of soil were suspended in $10 \mathrm{~mL}$ of sterile $0.9 \%(\mathrm{w} / \mathrm{v}) \mathrm{NaCl}$ solution and vortexed for $30 \mathrm{~s}$. The supernatant was serially diluted $\left(10^{-1}\right.$ to $10^{-6}$ ) and spread in $1 / 100$ diluted ( 0.08 g per liter) Difco Nutrient Broth - NB (Becton Dickinson, United States) plates (1/100

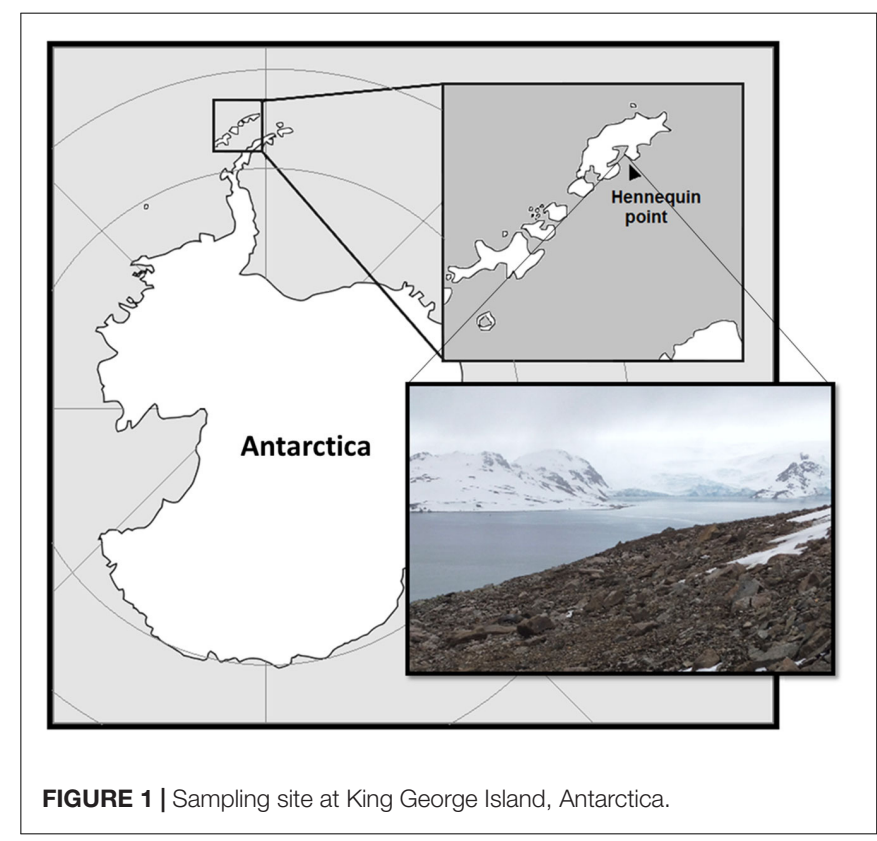


$\mathrm{NB}$ ), solidified using $0.7 \%(\mathrm{w} / \mathrm{v})$ Gellan gum (CP Kelco, United States) with the addition of $\mathrm{MgSO}_{4} \cdot 7 \mathrm{H}_{2} \mathrm{O}(0.1 \% \mathrm{w} / \mathrm{v})$ as a divalent cation to promote solidification; 8-10 plates for each dilution were prepared. Plates were then incubated at $12^{\circ} \mathrm{C}$ in the absence of light for up to 15 weeks. To avoid desiccation, plates were incubated inside polyethylene bags (Davis et al., 2011). Colony formation was followed weekly under a stereo microscope (up to $\times 40$ magnification) and new colonies were marked as they appeared. Selection of the isolates was performed by picking only colonies that appeared after 4 weeks of incubation. Colonies were chosen based on their morphological characteristics, therefore picking similar colonies that developed on the plates at the same time was avoided. For isolation, the chosen colonies were streaked on new 1/100 NB plates. After isolation, cells were re-streaked on $1 / 100 \mathrm{NB}$ plates, $1 / 10 \mathrm{NB}$ plates (10 times less diluted), and Difco Reasoner's 2A agar - R2A (Becton Dickinson, United States) for evaluating growth preferences. Whenever possible, cells were grown in liquid $1 / 100 \mathrm{NB}, 1 / 10 \mathrm{NB}$, or R2A broth for generating biomass for cryostock preparation. Many of the isolates, however, did not developed well on liquid media. In these cases, biomass was collected from colonies in petri dishes. Stocks were prepared with $30 \% \mathrm{v} / \mathrm{v}$ glycerol and maintained at $-80^{\circ} \mathrm{C}$. All isolates are listed in Supplementary Table 1.

\section{DNA Extraction and 16S Sequencing}

Genomic DNA was extracted using a PureLink Genomic DNA Mini Kit (Invitrogen, United States). 16S rRNA genes were amplified (initial denaturation step at $98^{\circ} \mathrm{C}$ for $5 \mathrm{~min}$, followed by 30 cycles at $95^{\circ} \mathrm{C}$ for $30 \mathrm{~s}, 50^{\circ} \mathrm{C}$ for $30 \mathrm{~s}$ and $72^{\circ} \mathrm{C}$ for $2 \mathrm{~min}$, followed by a final step at $72^{\circ} \mathrm{C}$ for $3 \mathrm{~min}$ ) using the universal primers 27F and 1401R, purified using the GeneJet PCR purification kit (Thermo Scientific, United States), and sequenced using the BigDye Terminator kit (Applied Biosystems, United States), using the 27F, $1401 \mathrm{R}$, and $518 \mathrm{uF}$ primers. Sequences were obtained by Sanger sequencing with an Abi Prism 3130xl Genetic Analyzer (Applied Biosystems, United States). Near the full sequence (1400 base pairs) of $16 \mathrm{~S}$ rRNA was obtained. Sequences were deposited in Genbank under the access codes (KX990222.1 to KX990262.1). Phylogenetic trees were built using MEGA6 (Tamura et al., 2013), sequence alignments were performed with Muscle, and tree estimates were obtained using the maximum likelihood test (500 bootstraps). For sequence acquirement and analysis, EzTaxon (Kim et al., 2012) was used to obtain the top hits including type material sequences (described species). For environmental and cultured bacteria (non-type material sequences), Megablast (Genbank) top hits were used. In addition to EzTaxon and the NCBI database, our isolate's sequences were also analyzed using the Silva database Project (Quast et al., 2013).

\section{Fluorescence Microscopy}

For fluorescence microscopy imaging, cells were collected directly from plates and suspended in $50 \mu \mathrm{l}$ of sterile $0.9 \%$ (w/v) $\mathrm{NaCl}$ solution. For cell membrane staining, the fluorescent dye FM1-43 (Invitrogen, United States) was used at a final concentration of $50 \mu \mathrm{g} \cdot \mathrm{mL}^{-1}$. For DNA staining, the dye DAPI (Thermo Fisher, United States) was used at a final concentration of $15 \mu \mathrm{g} \cdot \mathrm{mL}^{-1}$. For images, cells were placed over agar-pads [0.9\% (w/v) $\mathrm{NaCl}$ solution solidified with $1.5 \% \mathrm{w} / \mathrm{v}$ agarose] and observed on a Nikon Eclipse TiE microscope (Nikon, Japan) equipped with a Plan APO VC Nikon $100 \times$ objective $(\mathrm{NA}=1.4)$, a 25-mm SmartShutter, and Andor EMCCD i-Xon camera.

\section{Raman Spectroscopy and Pigments Characterization}

For pigment evaluation, the isolates were analyzed by Raman spectroscopy, using a Renishaw (Renishaw PLC, Wotton-underEdge, United Kingdom) inVia micro-Raman Spectrometer with laser line (532 nm), 50× objective, and CCD detector, and a Horiba-Jobin-Yvon micro-Raman Spectrometer with triple monochromator, laser line at $457 \mathrm{~nm}, 100 \times$ objective and CCD detector. The isolates were analyzed without further sample preparation, by removing the colonies from plates and depositing them onto glass slides. For Aphanothece stagnina and Halobacterium salinarum NRC-1 spectrum, cells were collected from liquid growth (BG11 media for Aphanothece and ATCC 217 medium for Halobacterium) centrifuged for $2 \mathrm{~min}$ at $5000 \times \mathrm{g}$, the supernatant was discarded, and the pellet was deposited on glass slides. Low laser power was used to avoid thermal or photochemical damage. The acquired spectra were analyzed using the software Fityk (Wojdyr, 2010) and peak positions were estimated after peak fitting.

\section{RESULTS AND DISCUSSION}

\section{Microorganisms Belonging to Rare or Recently Described Genera Were Isolated during the First 8 Weeks of Incubation}

Our isolation procedures focused on cold-tolerant, slow-growing microorganisms. With that in mind, we concentrated our efforts on colonies that developed on diluted medium plates after 4 weeks of incubation at $12^{\circ} \mathrm{C}$. Since our objective was not to perform an ecological or abundance characterization of the sample, the fast-growing bacterial community present was not deeply studied in this work. In the same way, we did not collect all slow-growing colonies that appeared on the plates, as several similar slow-growing morphotypes were observed after the same incubation period. However, we observed that during the first weeks most of the bacteria that grew belonged to the genus Arthrobacter and Sphingomonas, inferred by 16S rRNA sequencing (data not shown), as well as several colonies that visually appeared to be fungi and yeasts, which were confirmed by observation under a microscope.

Ultimately, we selected 41 morphologically distinct bacterial colonies that grew in the period of 4-14 weeks of incubation (Supplementary Table 1). Considering the top-hit 16S rRNA sequence matches of our set of slowgrowing isolates, it was possible to classify them in at least 26 distinct genera: Sphingomonas, Phycicoccus, Quadrisphaera, Friedmanniella, Methylobacterium, Lapillicoccus, Polaromonas, Motilibacter, Rhodoferax, Kineosporia, Nocardioides, Flavitalea, 
TABLE 1 | Isolates belonging to rarely isolated genera or potentially undescribed generas and families.

\begin{tabular}{|c|c|c|c|c|}
\hline Isolate code & Weeks to isolation & Accession code & $\begin{array}{l}\text { Highest 16S rRNA sequence similarity } \\
\text { (Type strain-Eztaxon) }\end{array}$ & $\begin{array}{l}\text { Highest 16S rRNA sequence similarity } \\
\text { (Genbank) }\end{array}$ \\
\hline Ap07E & 5 & KX990227.1 & $\begin{array}{l}\text { Quadrisphaera granulorum AG019 } \\
(98.2 \%)-[\text { AY831385] }\end{array}$ & $\begin{array}{l}\text { Quadrisphaera granulorum strain CS4 } \\
(99 \%) \text { - [AM887695.2] }\end{array}$ \\
\hline Ap15E & 4 & KX990235.1 & $\begin{array}{l}\text { Motilibacter peucedani RP-AC37 } \\
(97.46 \%)-[\text { FM998003] }\end{array}$ & $\begin{array}{l}\text { Actinomycetales bacterium OS1-23 } \\
(98 \%)-[\text { FN649461.1] }\end{array}$ \\
\hline Ap13E & 5 & KX990233.1 & $\begin{array}{l}\text { Lapillicoccus jejuensis R-Ac013 } \\
(98.4 \%)-[\mathrm{AM} 398397]\end{array}$ & $\begin{array}{l}\text { Lapillicoccus jejuensis R-Ac013 } \\
(98 \%)-[\text { AM398397] }\end{array}$ \\
\hline Ap19E & 7 & KX990239.1 & $\begin{array}{l}\text { Flavitalea populi HY-50R } \\
(96.72 \%)-[\mathrm{HM} 130561]\end{array}$ & $\begin{array}{l}\text { Uncultured Flavitalea sp. clone SNNP_2012-54 } \\
(99 \%)-[\text { JX114387.1] }\end{array}$ \\
\hline Ap23E & 8 & KX990242.1 & $\begin{array}{l}\text { Polymorphobacter multimanifer 272-7 } \\
(95.66 \%)-[A B 649056]\end{array}$ & $\begin{array}{l}\text { Uncultured alpha proteobacterium clone } \\
\text { IC4022 (99\%) - [HQ622730.1] }\end{array}$ \\
\hline Ap32E & 8 & KX990250.1 & $\begin{array}{l}\text { Paracraurococcus ruber NS89 } \\
(95.62 \%)-[\mathrm{D} 85827]\end{array}$ & $\begin{array}{l}\text { Uncultured endolithic bacterium clone } \\
\text { SM_01_BAC (99\%) - [AB473915.1] }\end{array}$ \\
\hline Ap20E & 8 & KX990240.1 & $\begin{array}{l}\text { Lapillicoccus jejuensis R-Ac013 } \\
\text { (98.12\%) - [AM398397] }\end{array}$ & $\begin{array}{l}\text { Uncultured Lochheadia sp. clone Plot4-B02 } \\
(98 \%)-[E \cup 449557.1]\end{array}$ \\
\hline Ap25E & 9 & KX990244.1 & $\begin{array}{l}\text { Frankia alni ACN14A } \\
(93.35 \%)-[C T 573213]\end{array}$ & $\begin{array}{l}\text { Uncultured bacterium clone MA03C08 } \\
(98 \%)-[\text { FM873556.1] }\end{array}$ \\
\hline Ap29E & 9 & KX990248.1 & $\begin{array}{l}\text { Rhodopila globiformis DSM } 161 \\
(93.49 \%)-[D 86513]\end{array}$ & $\begin{array}{l}\text { Uncultured alpha proteobacterium clone } \\
\text { IC4004 (96\%) - [HQ622721.1] }\end{array}$ \\
\hline Ap42E & 10 & KX990257.1 & $\begin{array}{l}\text { Acidothermus cellulolyticus ATCC } 43068 \\
(92.08 \%)-[\text { [CP000481] }\end{array}$ & $\begin{array}{l}\text { Uncultured bacterium clone ncd260b10c1 } \\
(97 \%)-[H M 270084.1]\end{array}$ \\
\hline Ap46E & 11 & KX990261.1 & $\begin{array}{l}\text { Frankia alni ACN14A } \\
(93.39 \%)-[C T 573213]\end{array}$ & $\begin{array}{l}\text { Uncultured bacterium clone MA03C08 } \\
(98 \%)-[F M 873556.1]\end{array}$ \\
\hline Ap43E & 12 & KX990258.1 & $\begin{array}{l}\text { Rhodopila globiformis DSM } 161 \\
(92.55 \%)-[D 86513]\end{array}$ & $\begin{array}{l}\text { Uncultured bacterium clone Bas-7-52 } \\
(97 \%)-[G Q 495410.1]\end{array}$ \\
\hline Ap44E & 12 & KX990259.1 & $\begin{array}{l}\text { Modestobacter versicolor CP153-2 } \\
(94.5 \%)-[\text { AJ871304] }\end{array}$ & $\begin{array}{l}\text { Uncultured bacterium clone 3-952 } \\
(98 \%)-[\text { KC554168] }\end{array}$ \\
\hline Ap36E & 13 & KX990253.1 & $\begin{array}{l}\text { Beijerinckia derxii subsp. venezuelae DSM } 2329 \\
(94.28 \%)-[\text { AJ563934] }\end{array}$ & $\begin{array}{l}\text { Uncultured bacterium clone 1174-901-15 } \\
(98 \%)-[A B 128887.1]\end{array}$ \\
\hline Ap38E & 13 & KX990255.1 & $\begin{array}{l}\text { Conexibacter woesei DSM } 14684 \\
(93.7 \%)-[\text { CP001854] }\end{array}$ & $\begin{array}{l}\text { Rubrobacteridae bacterium Gsoil } 1167 \\
(99 \%)-[\text { AB245333.1] }\end{array}$ \\
\hline Ap45E & 14 & KX990260.1 & $\begin{array}{l}\text { Conexibacter arvalis KV-962 } \\
(94.46 \%)-[A B 597950]\end{array}$ & $\begin{array}{l}\text { Uncultured actinobacterium clone UMAB-cl-13 } \\
(98 \%)-[\text { FN811197.1] }\end{array}$ \\
\hline
\end{tabular}

Polymorphobacter, Hymenobacter, Ryzobacter, Nakamurella, Angustibacter, Bradyrhizobium, and Marmoricola. Ten isolates scored highest similarity within the genera Paracraurococcus, Rhodopila, Acidothermus, Frankia, Beijerinckia, Modestobacter, and Conexibacter, although for these isolates, due to the low $16 \mathrm{~S}$ rRNA sequence similarity and their position in our phylogenetic trees, they all likely belong to undescribed genera. Although there are established "cutoff" values for determining the novelty of an isolate based on 16S rRNA sequence similarity, there is no consensus for this value (Janda and Abbott, 2007). Conservative thresholds consider novel species when 16S rRNA sequence similarity is less than $97 \%$, novel genera and families when these values are between 95 and 91\%, and novel order when the values are below 91\% (Nichols et al., 2010; Rossi-Tamisier et al., 2015). However, more recent studies propose cutoff values of $98.7 \%$ for novel species (Stackebrandt and Ebers, 2006). In addition, as recently pointed out by Rossi-Tamisier et al. (2015), classification for novel genera and families must also consider minimum and maximum similarity values observed among species already described for that particular group (Rossi-Tamisier et al., 2015), since there is large variation between different groups of bacteria. For this manuscript discussion, the conservative cutoff values will be considered, as well as the position on phylogenetic trees.
Our methodology was successful in obtaining novel, previously uncultured microorganisms from an Antarctic soil sample. Microorganisms belonging to rare or recently described genera (Table 1), for example Lapillicoccus, Flavitalea, Quadrisphaera, Motilibacter, and Polymorphobacter were obtained, as determined by phylogenetic trees (Supplementary Figures 1A-E).

The genus Flavitalea was originally described in 2011 (Wang et al., 2011) and has three species described to date. Our isolate Ap19E clustered together in our phylogenetic tree with F. populi and F. gansuensis (Supplementary Figure 1B), which suggest that these organisms belong to the same genus. The genus Lapillicoccus was first described in 2007 (Lee and Lee, 2007). The type-species Lapillicoccus jejuensis R-Ac013 is the only currently described species within the genus. We isolated two morphologically distinct bacteria (Ap13E and Ap20E) that, because of the $16 \mathrm{~S}$ rRNA sequence similarity and position within the phylogenetic tree (Table 1 and Supplementary Figure 1A), probably belongs to the Lapillicoccus genus.

The type strain Q. granulorum AG019 was described in 2005 (Maszenan, 2005), and it is the only described species of the genus. Our isolate Ap07E formed an independent branch together with Q. granulorum AG019 (Supplementary Figure 1C), 
Additional assays performed with our isolate demonstrated that the Ap07E strain is capable of growing at $4^{\circ} \mathrm{C}$ and does not develop at temperatures of $30^{\circ} \mathrm{C}$ or higher (data not shown), whereas Q. granulorum AG019 has been reported as not capable of growing at temperatures below $15^{\circ} \mathrm{C}$, and with optimum growth temperature of $37^{\circ} \mathrm{C}$ (Maszenan, 2005).

Polymorphobacter multimanifer was first described in 2014 (Fukuda et al., 2014) and the genus has two described species to date. Our isolate Ap23E grouped together with these two species in our phylogenetic tree (Supplementary Figure 1D), however, due to the low $16 \mathrm{~S}$ rRNA sequence similarity with the closest type strain (95.66\% similarity with Polymorphobacter multimanifer 272-7)it is quite possible that our isolate Ap23E might constitute a new Polymorphobacter species. Finally, the species Motilibacter peucedani was described in 2012 (Lee, 2012) and a subsequent publication describing a second species, Motilibacter rhizosphaerae, also proposed it as a new genus and new family of the suborder Frankinae, family Motilibacteraceae (Lee, 2013). Due to the position within the phylogenetic tree (Supplementary Figure 1E) we suggest that our isolate Ap15E belongs to the same genus and family.

\section{Longer Incubation Periods Allowed Isolation of Members of Potentially Novel Bacterial Genera and Families}

In addition, of our slow growing set of isolates (Supplementary Table 1), we obtained organisms with $16 \mathrm{~S}$ rRNA sequence similarity ranging from 92.08 to $94.6 \%$ to any other known cultured species (Table 1; Isolates Ap25E, Ap29E, Ap36E, Ap38E Ap42E, Ap43E, Ap44E, Ap45E, and Ap46E). These isolates were obtained after 8 to 14 weeks of incubation. Particularly for these isolates, microscopic observations of the plates were vital for isolation, since many of them developed as extremely small colonies and were surrounded by faster growing bacterial colonies and filamentous fungi that could eventually overgrow them.

The isolates Ap29E, Ap32E, Ap36E and Ap43 were considered Proteobacteria. They all share low $16 \mathrm{~S}$ rRNA sequence similarity ( $\sim 94 \%$ ) with the closest described species (Table 1) and with microbes belonging to non-type material (94-95\%) except for Ap32E. This isolate, Ap32E, clustered with a sequence of Acetobacteraceae bacterium WS10 in our phylogenetic tree (Supplementary Figure 2A). Recently, Kim et al. (2016) have proposed the isolate WS10 as Dankookia rubra gen. nov. It is possible therefore, after confirmation of these new genera that our isolate will belong to the Dankookia genus, as it shares $98 \%$ sequence similarity with the WS10 strain.

The isolates Ap32E, Ap29E, Ap43E belong to the big bacterial family Acetobacteraceae (Figure 2A). Ap29E and Ap43E share 99\% 16S rRNA sequence similarity and have similar phenotypical characteristics, suggesting these two isolates belong to the same species. The isolate Ap36E grouped with bacteria from the order Rhizobiales (Figure 2B). However, due to their low $16 \mathrm{~S}$ rRNA sequence similarity, they did not appear to cluster into any described genus (Ap29E and Ap43E) or family (Ap36E) in our phylogenetic trees. By constructing a tree with the addition of environmental sequences and cultured bacteria, Ap29E and Ap43E cluster together with several sequences belonging to cold environments, glacier ice, snow, and ice cores, possibly indicating a cold and dry adapted, but yet undescribed genus (Supplementary Figure 2A), whereas Ap36E clustered together with environmental sequences found in both cold and warm environments including marine sediments, glaciers, snow, and gastrointestinal samples (Supplementary Figure 2D). Such sequences, together with our isolate, form an independent branch from the closest families.

The isolates Ap25E, Ap42E, Ap44E, and Ap46E belong to the order Actinomycetales. They all share low 16S rRNA sequence similarity with any described species (Table 1), some of them as low as $92 \%$. By constructing a phylogenetic tree with the highest 16S rRNA sequence similarities (type material sequences), we could not group them into any described genus or family (Figure 3A). None of these organisms share 16S rRNA sequence similarity higher than $94 \%$ with any cultured bacteria (non-type material, evaluated using Megablast). As a highlight, Ap25E and Ap46E isolates clustered together in a large group, containing several sequences belonging to mountain environments (Tang et al., 2016) and desert environments (Supplementary Figure 2B). Three of such sequences were reported at the Yungay region, a hyperarid region at the Atacama desert (Connon et al., 2007), and the authors also proposed such sequences as belonging to a novel, undescribed genera. Curiously, the authors attempted to isolate bacteria from such samples, but did not manage to retrieve isolates from the cluster, after 3 weeks of incubation.

The Yungay environment has extreme low water activity, which could force microbes to replicate during rare precipitation events that might occur (Connon et al., 2007). In this scenario, the slow growth behavior of our isolates both during and after isolation could even represent an environmental adaptation of this bacterial cluster to such an environment and might be the reason that no representatives of such group had been isolated until now. Considering that our isolates Ap25E and Ap46E are the first cultured representatives from this cluster of bacteria, their characteristics may be useful for extrapolating this adaptive behavior to other deserts, such as the Atacama, as well help in further isolation attempts.

Finally, the isolates Ap38E and Ap45E grouped together with bacteria belonging to a deep branching phylogenetic lineage within the phylum Actinobacteria, class Thermoleophilia, order Solirubrobacterales (Figure 3B), sharing 94\% 16S rRNA sequence similarity with other described species (Table 1). Sequences of organisms belonging to class Thermoleophilia have been constantly reported in samples from Antarctica (Chong et al., 2012; Aislabie et al., 2013; Kumar et al., 2013; Rampelotto et al., 2015; Ji et al., 2016; Pudasaini et al., 2017), reaching relative abundances of $15 \%$ in some samples (Ji et al., 2016). Although highly present, no isolate of this class has been reported from this type of environment to date, making this the first report of Thermoleophilia isolation from an Antarctic sample in addition to the novelty of this species. We observed that within 80 days, both isolates (Ap38E and Ap45E) grew at 10 and $15^{\circ} \mathrm{C}$, whereas no growth was observed at $30^{\circ} \mathrm{C}$. At $25^{\circ} \mathrm{C}$, only Ap38E presented weak growth, but less than that observed at 15 and 


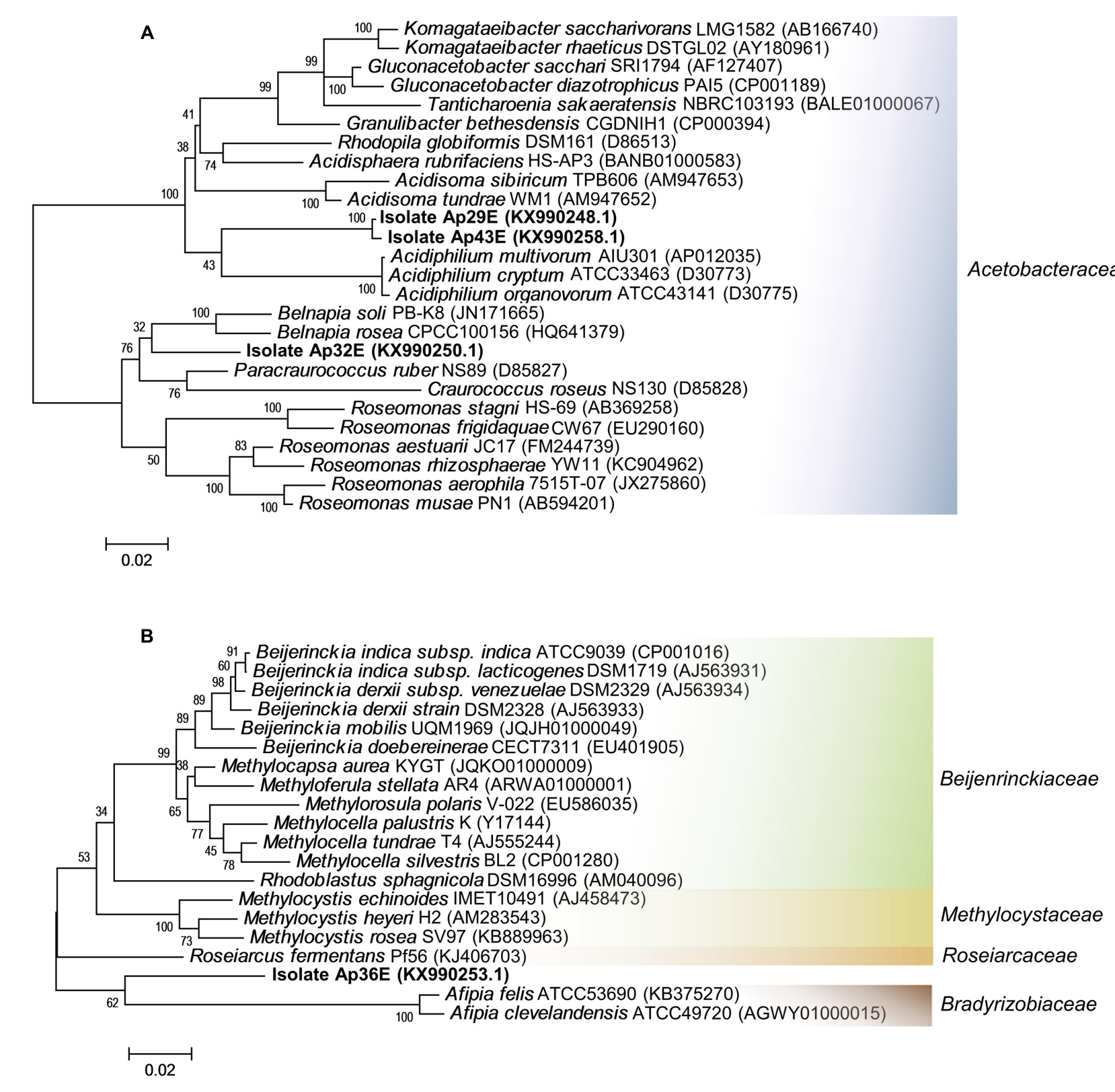

FIGURE 2 | Maximum likelihood phylogenetic trees of the isolates Ap29E, Ap32E, Ap36E and Ap43E. (A) Phylogenetic affiliation of the isolates Ap29E, Ap32E and Ap43E and the most similar 16S sequences of type material organisms. (B) Phylogenetic affiliation of the isolates Ap36E and the most similar 16S sequences of type material organisms. Scale bar indicates a change of 0.02 per nucleotide.

$10^{\circ} \mathrm{C}$ (Supplementary Figure 3). This indicates that these isolates can be potential psychrophilic microorganisms, an important feature considering that all described species within the order Solirubrobacterales are mesophilic (Whitman and Suzuki, 2015; Foesel et al., 2016).

The phylogenetic tree (using type material sequences) did not place our isolates (Ap38E and Ap45E) in any described genera or family within the order Solirubrobacterales. Our isolates grouped together and formed a distinct branch near the families Conexibacteraceae, Patulibacteraceae, Solirubrobacteraceae and the recently described Parviterribacteraceae (Foesel et al., 2016), as can be seen in Figure 3B. Although grouped together in an independent branch, Ap38E and Ap45E share only $95 \%$ of $16 \mathrm{~S}$ rRNA sequence similarity between each other, suggesting they are two different species within the same family.

By including the top hits of environmental sequences and cultured but non-type material in the phylogenetic tree (Supplementary Figure 2C) we observed that our isolates form a group that cluster with environmental sequences from multiple geographic locations all subjected to great UV influx and/or low water activity: Antarctica (Chong et al., 2012), 


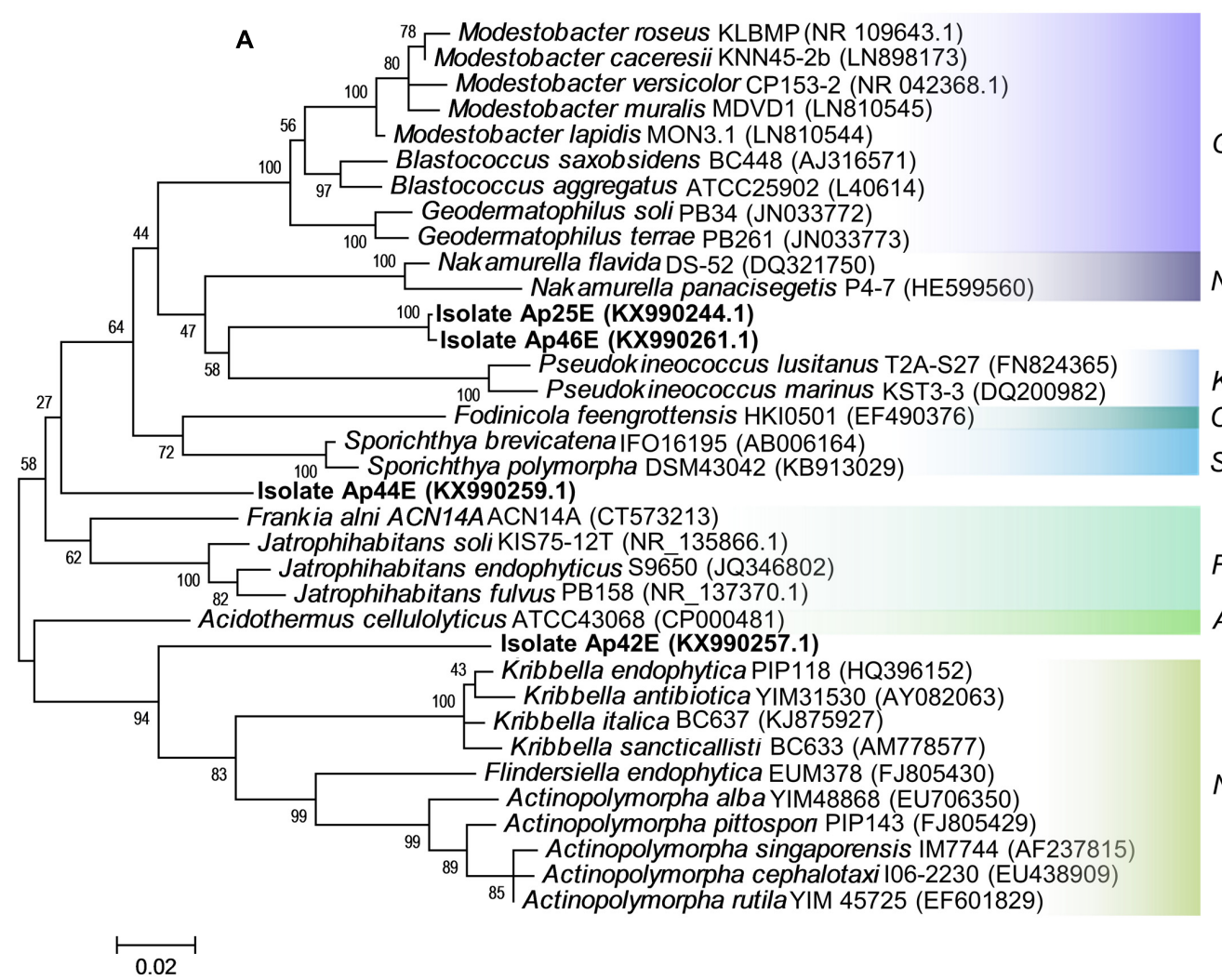

B

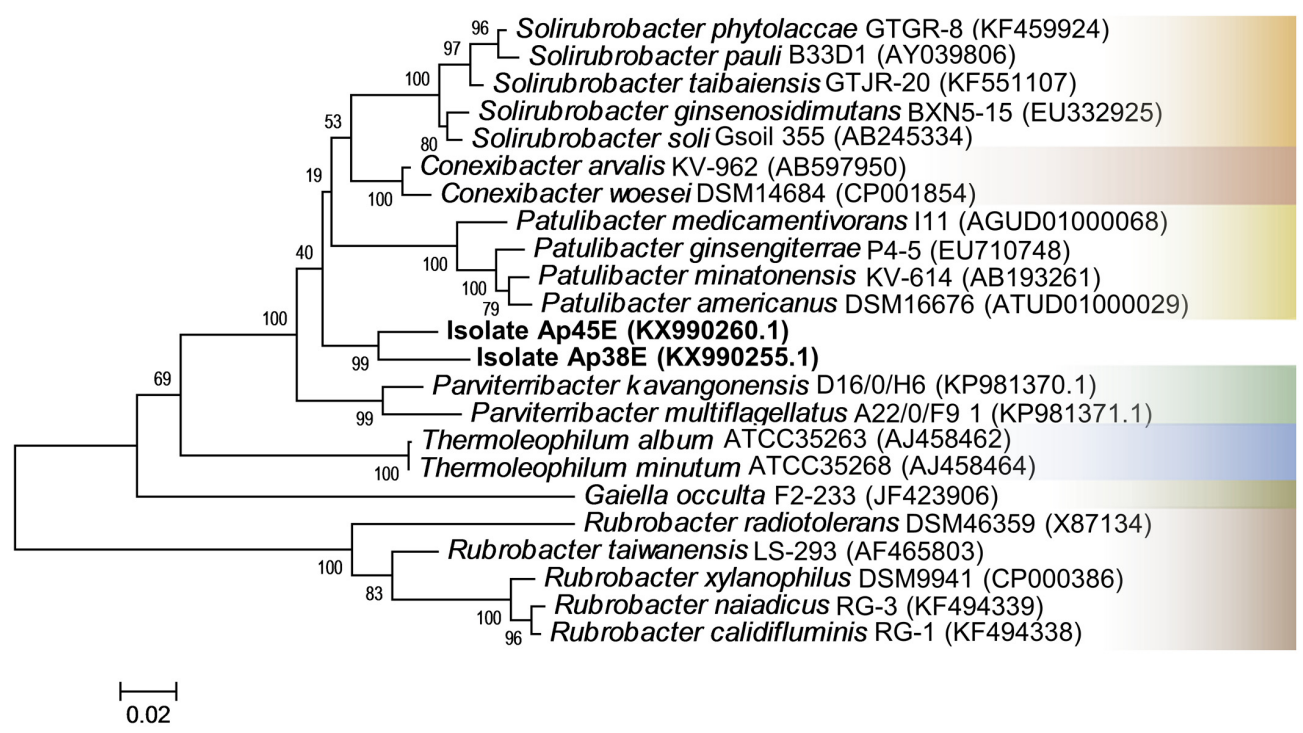

Solirubrobacteraceae

Conexibacteraceae

Patulibacteraceae

Parviterribacteraceae

Thermoleophilaceae

Gaiellaceae

Rubrobacteraceae

FIGURE 3 | Maximum likelihood phylogenetic trees of the isolates Ap25E, Ap38E, Ap42E, Ap44E, Ap45E, Ap46E. (A) Phylogenetic affiliation of the isolates Ap25E, Ap42E, Ap44E and Ap46E and the most similar 16S sequences of type material organisms. (B) Phylogenetic affiliation of the isolates Ap38E, and Ap45E, and the most similar $16 \mathrm{~S}$ sequences of type material organisms. Scale bar indicates a change of 0.02 per nucleotide.

mineral surface biofilms (Ragon et al., 2012), Tibetan soil, and the Llullaillaco volcano $(>6000 \mathrm{~m})$ and the Atacama Desert (Lynch et al., 2012), which can suggest a highly adapted group of bacteria to such extreme conditions. Interestingly, our isolate Ap38E also clustered together with two sequences: Rubrobacteridae bacterium Gsoil 319 (accession code AB245332) and Rubrobacteridae bacterium Gsoil 1167 (accession code AB245333) sharing 99\% 16S rRNA sequence similarity with both 
of these sequences. The isolate Ap45 on the other hand, shares only $95 \%$ similarity with these two sequences. However, both the Rubrobacteridae bacterium Gsoil 319 and Rubrobacteridae bacterium Gsoil 1167 sequences were deposited in GenBank in 2006, but have not been associated with any publication until now. Despite the information that both organisms seem to have been isolated from a ginseng field (available on
GenBank), there is no additional information regarding such isolates, which makes any possible comparison with our two isolates difficult. Therefore, our isolates have a high potential to constitute two different novel, distinct species within the order Solirubrobacterales.

In fact, our isolates Ap38E and Ap45E have distinct colony morphologies, but both isolates are small rods of $0.6-1.2 \mu \mathrm{m}$
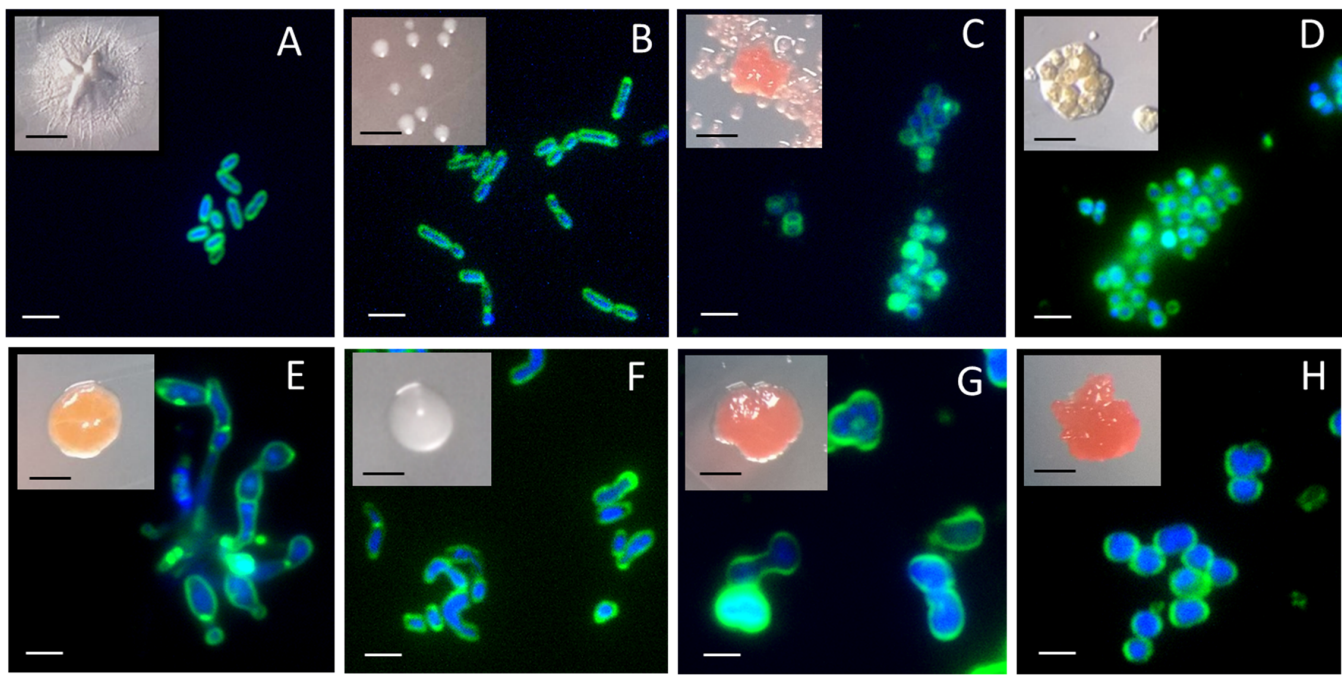

FIGURE 4 | Colonies and fluorescence microscopy images of isolates obtained from the Hennequin point sample on diluted NB media. (A) Isolate Ap38E; (B) Isolate Ap45E; (C) Isolate Ap25E. Similar images were obtained for isolate Ap46E and therefore are not shown; (D) Isolate Ap42E; (E) Isolate Ap44E; (F) Isolate Ap36E;

(G) Isolate Ap29E. Similar images were obtained with isolate Ap43E and therefore are not shown; (H) Isolate Ap32E. Membrane were stained with FM1-43 and DNA were stained with DAPI. Black scale bars: $1 \mathrm{~mm}$. White scale bars: $2 \mu \mathrm{m}$.

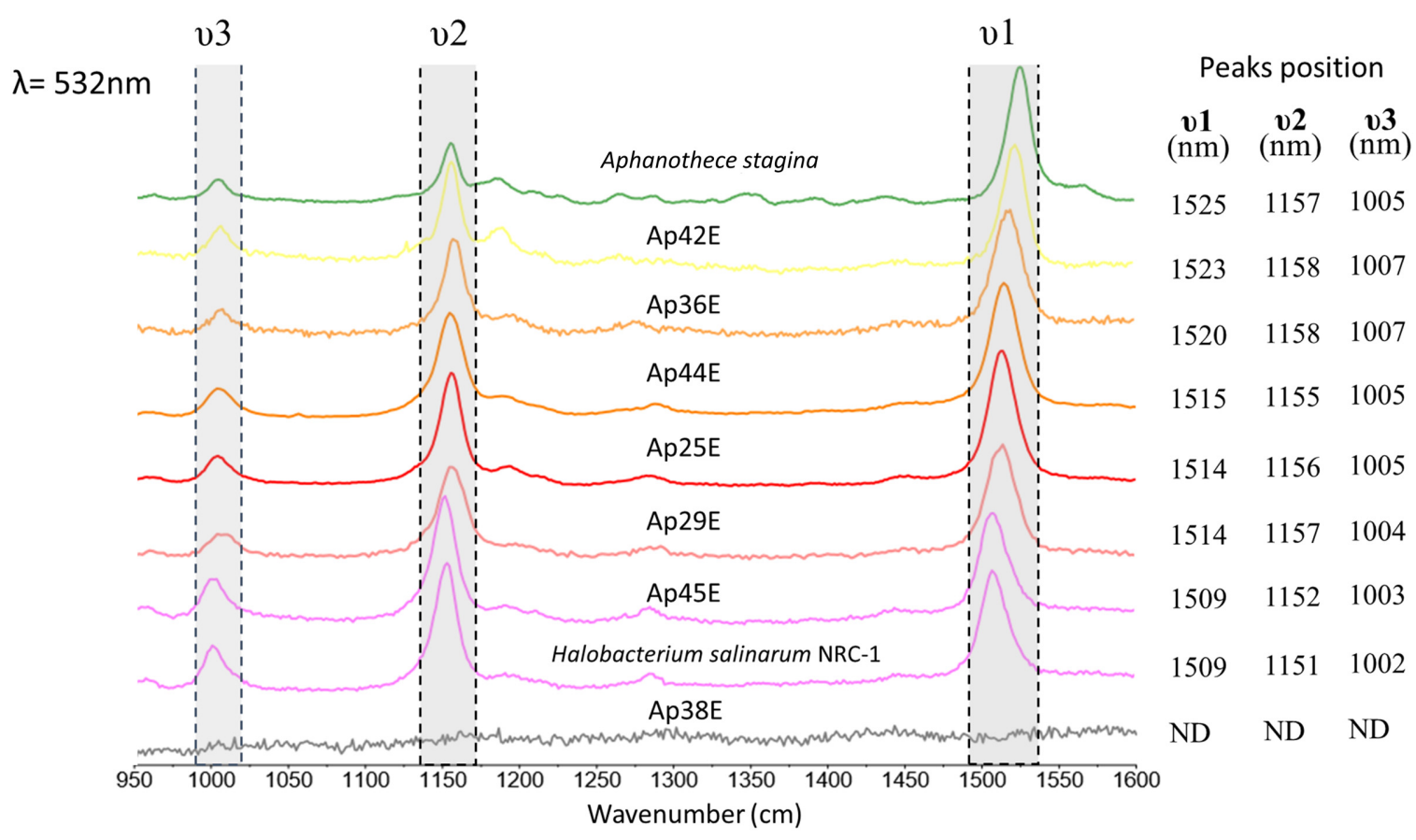

FIGURE 5 | Raman spectra of the isolated colonies with excitation at $532 \mathrm{~nm}$ with the most intense Raman bands of carotenoids. 
(Figures 4A,B), similar in size with the bacteria to the family Conexibacteraceae (Monciardini, 2003; Seki et al., 2012). The isolates Ap25E, Ap46E, and Ap42E are also composed of small cells, however, they are coccoid in shape and grow in aggregates (Figures 4C,D). To note, the isolates Ap25E and Ap46E, which clustered with several sequences found in desert and mountain soils, had strong red pigmentation. The isolate Ap44E grows as orange colored colonies, and its cells are filamentous and aggregated (Figure 4E). The cell morphology of isolate Ap36E is curious: it appears to be dimorphic and undergo asymmetric septation (Figure 4F). Such features have already been described for other Rhizobiales bacteria (Brown et al., 2012). Isolates Ap29E, Ap32E, and Ap43E form colonies with intense red color (Figures 4G,H). Microscopic observations showed that they are all coccoid cells $(\sim 2 \mu \mathrm{m})$.

Pigments were characterized using Raman spectroscopy (Figure 5). Carotenoids cause very intense Raman bands, characterized by three typical peaks, at 1520, 1150, and $1000 \mathrm{~cm}^{-1}$ (de Oliveira et al., 2010; Jehlička et al., 2014a). With the exception of isolate Ap38E, carotenoids were observed in all other isolates. Surprisingly, Ap45E and Ap36E also produced carotenoids under our growth conditions, despite not having visible colony coloration (Figures 4B,F). To highlight, we observed that the Raman spectra acquired for isolate Ap45E (which forms light-pink colonies) is remarkably similar to the spectra acquired for the Halobacterium salinarum NCR-1, a microorganism for which the Raman signal is due to bacterioruberin, represented by low stretching values for all peaks, when compared with other carotenoids (Jehlička et al., 2014b). Bacterioruberin is an unusual C50 carotenoid constantly studied and analyzed by Raman spectroscopy (Imperi et al., 2007; Morillas et al., 2015), and present in some halophilic archaea and some actinobacteria belonging to the family Rubro bacteraceae (Saito et al., 1994; Imperi et al., 2007).

We sought to detect presence of bacteriochlorophyll, especially in isolates Ap29E and Ap43E, which are clustered near the Acidiphilium genera in our phylogenetic tree, a group that has been shown to produce bacteriochlorophyll (Kishimoto et al., 1995). However, we failed to detect characteristic peaks (750, 910, and $1630 \mathrm{~cm}^{-1}$ ) for the pigment (Donohoe et al., 1988; Jehlička et al., 2014a) for Ap29E in our growth conditions, even when using different Raman lasers with the best resonance for chlorophyll and bacteriochlorophyll (Supplementary Figure 4).

More concentrated medium (NB 1/10) slightly improved cell growth for most of the isolates. However, with the exception of isolate Ap32E, the isolates Ap25E, Ap29E, Ap36E, Ap38E, Ap42E, Ap43E, Ap44E, Ap45E, and Ap46E failed to grow on R2A medium. R2A is commonly employed for bacterial isolation from Antarctica and similarly cold environmental samples (Skidmore et al., 2000; Aislabie et al., 2006, 2013; Clocksin et al., 2007; Steven et al., 2007; Vester et al., 2013; Grzesiak et al., 2015), as it is considered a low nutrient medium known to yield a high number of isolates (Reasoner and Geldreich, 1985). Most of our rare isolates failed to develop on $\mathrm{R} 2 \mathrm{~A}$, and therefore would have been missed if just R2A had been employed in this study.
We decided to investigate more deeply four isolates (Ap25E, Ap38E, Ap42E, and Ap45E), regarding their growth preferences, using a combination of pure and diluted media, neutral $(\mathrm{pH} 7)$ and more acidic $\mathrm{pH}(\mathrm{pH} 5) \mathrm{NB}$ media (5 and $100 \%)$, TSA media (5 and 100\%) and R2 media solidified with Gellan gum (10 and 100\%) (Supplementary Table 2). Interestingly, all tested isolates showed a preference trend toward neutral, diluted media; for some cases (Isolates Ap38E, Ap25E, and Ap45E), growth was only recorded on diluted media, suggesting that these organisms are indeed oligotrophic. In addition, it was not possible to improve growth speed of the isolates, at least in our tested conditions: isolates Ap25E and Ap45E still kept their slow-growth behavior.

As a highlight, using Gellan-gum as solidifying agent, we have managed to grow isolates Ap42E and Ap38E on R2 media. Ap38E developed well at diluted R2 media (10\%), however, it has not grown well on pure, $100 \%$ R2 media, suggesting that this medium does not achieve the oligotrophic requirements for this isolate (Supplementary Table 2). Once again, Ap42E and Ap38E failed to grow on R2A media (R2 solidified with Agarose), even when using colonies that developed on R2 media solidified with Gellan gum as inoculum.

Overall, our data demonstrate that is possible to retrieve recalcitrant bacteria from Antarctic samples using longincubation periods, oligotrophic media, low temperatures, and selecting for slow-growing bacteria. Such a strategy allowed us to retrieve several bacteria with low $16 \mathrm{~S}$ rRNA sequence similarity to any described isolate. However, several of such isolates clustered together not only with Antarctic samples, but also with sequences found in other cold, extreme habitats, such as glaciers, ice-cores, snow, mountain soil, epilithic biofilms and other deserts, like the Atacama and Taklamakan. As a highlight, we isolated two distinct, cold-adapted species belonging to the class Thermoleophilia, order Solirubrobacterales from Antarctica that due to their low $16 \mathrm{~S}$ rRNA sequence similarity with other described species, might belong to an undescribed genera or family. Currently, we are improving growth conditions of our isolates, which will allow the expansion of knowledge about slow-growing microbial organisms in cold-environments, their environmental roles, stress resilience, as well as increase taxonomic data.

\section{AUTHOR CONTRIBUTIONS}

$\mathrm{AP}, \mathrm{AB}, \mathrm{AF}$, and $\mathrm{FR}$ executed experiments and performed analysis of the data. AP and FR conceived the original idea and designed experiments. FR, DG, and VP conducted the samples' collection and transportation. All authors contributed to critical interpretation of the data, writing and revising the manuscript. All authors approved the final version manuscript.

\section{FUNDING}

We thank the Brazilian Astrobiology Research Unit (NAPAstrobio - PRP/USP) for the infrastructure and financial support, the CNPq - Proantar (Project Microsfera - 407816/2013-5) 
and $\mathrm{CNPq}$ - INCT-Criosfera projects for financial and logistic support. AB received a Doctoral Fellowship from The São Paulo Research Foundation - FAPESP (Process number 2012/23241-0).

\section{ACKNOWLEDGMENTS}

We also thank the Laboratory of Molecular Spectroscopy (IQUSP) for the Raman measurements and, in special, to the Ph.D. students Claudio Mendes D. D. Souza and Tatiana Casselli Penna

\section{REFERENCES}

Aislabie, J. M., Chhour, K.-L., Saul, D. J., Miyauchi, S., Ayton, J., Paetzold, R. F., et al. (2006). Dominant bacteria in soils of Marble Point and Wright Valley, Victoria Land, Antarctica. Soil Biol. Biochem. 38, 3041-3056. doi: 10.1016/j. soilbio.2006.02.018

Aislabie, J. M., Lau, A., Dsouza, M., Shepherd, C., Rhodes, P., and Turner, S. J. (2013). Bacterial composition of soils of the Lake Wellman area, Darwin Mountains, Antarctica. Extremophiles 17, 775-786. doi: 10.1007/s00792-0130560-6

Baker, B. J., Lazar, C. S., Teske, A. P., and Dick, G. J. (2015). Genomic resolution of linkages in carbon, nitrogen, and sulfur cycling among widespread estuary sediment bacteria. Microbiome 3, 14. doi: 10.1186/s40168-0150077-6

Bomar, L., Maltz, M., Colston, S., and Graf, J. (2011). Directed culturing of microorganisms using metatranscriptomics. mBio 2:e0012-11. doi: 10.1128/ mBio.00012-11

Brown, P. J. B., de Pedro, M. A., Kysela, D. T., Van der Henst, C., Kim, J., De Bolle, X., et al. (2012). Polar growth in the alphaproteobacterial order rhizobiales. Proc. Natl. Acad. Sci. U.S.A. 109, 1697-1701. doi: 10.1073/pnas. 1114476109

Bruns, A., Cypionka, H., and Overmann, J. (2002). Cyclic AMP and Acyl homoserine lactones increase the cultivation efficiency of heterotrophic bacteria from the Central Baltic Sea. Appl. Environ. Microbiol. 68, 3978-3987. doi: 10.1128/AEM.68.8.3978-3987.2002

Cavicchioli, R., Charlton, T., Ertan, H., Omar, S. M., Siddiqui, K. S., and Williams, T. J. (2011). Biotechnological uses of enzymes from psychrophiles. Microb. Biotechnol. 4, 449-460. doi: 10.1111/j.1751-7915.2011. 00258.x

Chong, C. W., Convey, P., Pearce, D. A., and Tan, I. K. P. (2012). Assessment of soil bacterial communities on Alexander Island (in the maritime and continental Antarctic transitional zone). Polar Biol. 35, 387-399. doi: 10.1007/s00300-0111084-0

Clocksin, K. M., Jung, D. O., and Madigan, M. T. (2007). Cold-active chemoorganotrophic bacteria from permanently ice-covered Lake Hoare, McMurdo Dry Valleys, Antarctica. Appl. Environ. Microbiol. 73, 3077-3083. doi: 10.1128/AEM.00085-07

Connon, S. A., Lester, E. D., Shafaat, H. S., Obenhuber, D. C., and Ponce, A. (2007). Bacterial diversity in hyperarid Atacama Desert soils. J. Geophys. Res. Biogeosci. 112, G04S17. doi: 10.1029/2006JG000311

Davis, K. E. R., Joseph, S. J., and Janssen, P. H. (2005). Effects of growth medium, inoculum size, and incubation time on culturability and isolation of soil bacteria. Appl. Environ. Microbiol. 71, 826-834. doi: 10.1128/AEM.71.2.826834.2005

Davis, K. E. R., Sangwan, P., and Janssen, P. H. (2011). Acidobacteria, Rubrobacteridae and Chloroflexi are abundant among very slow-growing and mini-colony-forming soil bacteria. Environ. Microbiol. 13, 798-805. doi: 10.1111/j.1462-2920.2010.02384.x

De Maayer, P., Anderson, D., Cary, C., and Cowan, D. A. (2014). Some like it cold: understanding the survival strategies of psychrophiles. EMBO Rep. 15, 508-517. doi: 10.1002/embr.201338170

de Oliveira, V. E., Castro, H. V., Edwards, H. G. M., and de Oliveira, L. F. C. (2010). Carotenes and carotenoids in natural biological samples: a Raman spectroscopic analysis. J. Raman Spectrosc. 41, 642-650. doi: 10.1002/jrs.2493 for their assistance during Raman Spectra acquisition. We thank Prof. Dr. João S. Yunes from FURG for gently donating the Aphanothece stagina for our work.

\section{SUPPLEMENTARY MATERIAL}

The Supplementary Material for this article can be found online at: http://journal.frontiersin.org/article/10.3389/fmicb. 2017.01346/full\#supplementary-material

Dedysh, S. N. (2011). Cultivating uncultured bacteria from northern wetlands: knowledge gained and remaining gaps. Front. Microbiol. 2:184. doi: 10.3389/ fmicb.2011.00184

D’Onofrio, A., Crawford, J. M., Stewart, E. J., Witt, K., Gavrish, E., Epstein, S., et al. (2010). Siderophores from neighboring organisms promote the growth of uncultured bacteria. Chem. Biol. 17, 254-264. doi: 10.1016/j.chembiol.2010. 02.010

Donohoe, R. J., Frank, H. A., and Bocian, D. F. (1988). Resonance Raman spectra and normal mode descriptions of a bacteriochlorophyll a model complex. Photochem. Photobiol. 48, 531-537. doi: 10.1111/j.1751-1097.1988.tb0 2857.x

Ferrari, B. C., Binnerup, S. J., and Gillings, M. (2005). Microcolony cultivation on a soil substrate membrane system selects for previously uncultured soil bacteria. Appl. Environ. Microbiol. 71, 8714-8720. doi: 10.1128/AEM.71.12.8714-8720. 2005

Foesel, B. U., Geppert, A., Rohde, M., and Overmann, J. (2016). Parviterribacter kavangonensis gen. nov., sp. nov. and Parviterribacter multiflagellatus sp. nov., novel members of Parviterribacteraceae fam. nov. within the order Solirubrobacterales, and emended descriptions of the classes Thermoleophilia and Rubrobacteria and their orders and families. Int. J. Syst. Evol. Microbiol. 66, 652-665. doi: 10.1099/ijsem.0.000770

Fukuda, W., Chino, Y., Araki, S., Kondo, Y., Imanaka, H., Kanai, T., et al. (2014). Polymorphobacter multimanifer gen. nov., sp. nov., a polymorphic bacterium isolated from antarctic white rock. Int. J. Syst. Evol. Microbiol. 64, 2034-2040. doi: 10.1099/ijs.0.050005-0

George, I. F., Hartmann, M., Liles, M. R., and Agathos, S. N. (2011). Recovery of as-yet-uncultured soil Acidobacteria on dilute solid media. Appl. Environ. Microbiol. 77, 8184-8188. doi: 10.1128/AEM.05956-11

Goordial, J., Davila, A., Lacelle, D., Pollard, W., Marinova, M. M., Greer, C. W., et al. (2016). Nearing the cold-arid limits of microbial life in permafrost of an upper dry valley, Antarctica. ISME J. 10, 1613-1624. doi: 10.1038/ismej. 2015.239

Grzesiak, J., Zdanowski, M. K., Górniak, D., Świątecki, A., AleksandrzakPiekarczyk, T., Szatraj, K., et al. (2015). Microbial community changes along the Ecology Glacier ablation zone (King George Island, Antarctica). Polar Biol. 38, 2069-2083. doi: 10.1007/s00300-015-1767-z

Gtari, M., Ghodhbane-Gtari, F., Nouioui, I., Ktari, A., Hezbri, K., Mimouni, W., et al. (2015). Cultivating the uncultured: growing the recalcitrant cluster-2 Frankia strains. Sci. Rep. 5:13112. doi: 10.1038/srep13112

He, X., McLean, J. S., Edlund, A., Yooseph, S., Hall, A. P., Liu, S.-Y., et al. (2015). Cultivation of a human-associated TM7 phylotype reveals a reduced genome and epibiotic parasitic lifestyle. Proc. Natl. Acad. Sci. U.S.A. 112, 244-249. doi: $10.1073 /$ pnas. 1419038112

Hug, L. A., Baker, B. J., Anantharaman, K., Brown, C. T., Probst, A. J., Castelle, C. J., et al. (2016). A new view of the tree of life. Nat. Microbiol. 1:16048. doi: $10.1038 / \mathrm{nmicrobiol} .2016 .48$

Imperi, F., Caneva, G., Cancellieri, L., Ricci, M. A., Sodo, A., and Visca, P. (2007). The bacterial aetiology of rosy discoloration of ancient wall paintings. Environ. Microbiol. 9, 2894-2902. doi: 10.1111/j.1462-2920.2007.01393.x

Janda, J. M., and Abbott, S. L. (2007). 16S rRNA gene sequencing for bacterial identification in the diagnostic laboratory: pluses, perils, and pitfalls. J. Clin. Microbiol. 45, 2761-2764. doi: 10.1128/JCM.01228-07

Janssen, P. H., Yates, P. S., Grinton, B. E., Taylor, P. M., and Sait, M. (2002). Improved culturability of soil bacteria and isolation in pure culture of novel 
members of the divisions Acidobacteria, Actinobacteria, Proteobacteria, and Verrucomicrobia. Appl. Environ. Microbiol. 68, 2391-2396. doi: 10.1128/AEM. 68.5.2391-2396.2002

Jehlička, J., Edwards, H. G. M., and Oren, A. (2014a). Raman spectroscopy of microbial pigments. Appl. Environ. Microbiol. 80, 3286-3295. doi: 10.1128/ AEM.00699-14

Jehlička, J., Edwards, H. G. M., Osterrothová, K., Novotná, J., Nedbalová, L., Kopeck1, J., et al. (2014b). Potential and limits of Raman spectroscopy for carotenoid detection in microorganisms: implications for astrobiology. Philos. Trans. A Math. Phys Eng. Sci. 372:20140199. doi: 10.1098/rsta.2014.0199

Ji, M., van Dorst, J., Bissett, A., Brown, M. V., Palmer, A. S., Snape, I., et al. (2016). Microbial diversity at Mitchell Peninsula, Eastern Antarctica: a potential biodiversity "hotspot”. Polar Biol. 39, 237-249. doi: 10.1007/s00300-015-1776-y

Kaeberlein, T. (2002). Isolating "uncultivable" microorganisms in pure culture in a simulated natural environment. Science 296, 1127-1129. doi: 10.1126/science. 1070633

Kim, O.-S., Cho, Y.-J., Lee, K., Yoon, S.-H., Kim, M., Na, H., et al. (2012). Introducing EzTaxon-e: a prokaryotic 16S rRNA gene sequence database with phylotypes that represent uncultured species. Int. J. Syst. Evol. Microbiol. 62, 716-721. doi: 10.1099/ijs.0.038075-0

Kim, W.-H., Kim, D., Kang, K., and Ahn, T.-Y. (2016). Dankookia rubra gen. nov., sp. nov., an alphaproteobacterium isolated from sediment of a shallow stream. J. Microbiol. 54, 420-425. doi: 10.1007/s12275-016-6054-3

Kishimoto, N., Fukaya, F., Inagaki, K., Sugio, T., Tanaka, H., and Tano, T. (1995). Distribution of bacteriochlorophyll a among aerobic and acidophilic bacteria and light-enhanced $\mathrm{CO}_{2}$-incorporation in Acidiphilium rubrum. FEMS Microbiol. Ecol. 16, 291-296.

Kopke, B., Wilms, R., Engelen, B., Cypionka, H., and Sass, H. (2005). Microbial diversity in coastal subsurface sediments: a cultivation approach using various electron acceptors and substrate gradients. Appl. Environ. Microbiol. 71, 7819-7830. doi: 10.1128/AEM.71.12.7819-7830.2005

Kumar, N., Grogan, P., Chu, H., Christiansen, C., and Walker, V. (2013). The effect of freeze-thaw conditions on arctic soil bacterial communities. Biology 2, 356-377. doi: 10.3390/biology2010356

Lee, S. D. (2012). Motilibacter peucedani gen. nov., sp. nov., isolated from rhizosphere soil. Int. J. Syst. Evol. Microbiol. 62, 315-321. doi: 10.1099/ijs.0. 030007-0

Lee, S. D. (2013). Proposal of Motilibacteraceae fam. nov., with the description of Motilibacter rhizosphaerae sp. nov. Int. J. Syst. Evol. Microbiol. 63, 3818-3822. doi: 10.1099/ijs.0.052357-0

Lee, S. D., and Lee, D. W. (2007). Lapillicoccus jejuensis gen. nov., sp. nov., a novel actinobacterium of the family Intrasporangiaceae, isolated from stone. Int. J. Syst. Evol. Microbiol. 57, 2794-2798. doi: 10.1099/ijs.0.64911-0

Lewis, K., Epstein, S., D’Onofrio, A., and Ling, L. L. (2010). Uncultured microorganisms as a source of secondary metabolites. J. Antibiot. 63, 468-476. doi: $10.1038 /$ ja.2010.87

Ling, L. L., Schneider, T., Peoples, A. J., Spoering, A. L., Engels, I., Conlon, B. P., et al. (2015). A new antibiotic kills pathogens without detectable resistance. Nature 517, 455-459. doi: 10.1038/nature14098

Lynch, R. C., King, A. J., Farías, M. E., Sowell, P., Vitry, C., and Schmidt, S. K. (2012). The potential for microbial life in the highest-elevation (\&gt;6000 m.a.s.l.) mineral soils of the Atacama region. J. Geophys. Res. Biogeosci. 117, G02028. doi: 10.1029/2012JG001961

Maszenan, A. M. (2005). Quadrisphaera granulorum gen. nov., sp. nov., a Grampositive polyphosphate-accumulating coccus in tetrads or aggregates isolated from aerobic granules. Int. J. Syst. Evol. Microbiol. 55, 1771-1777. doi: 10.1099/ ijs.0.63583-0

Monciardini, P. (2003). Conexibacter woesei gen. nov., sp. nov., a novel representative of a deep evolutionary line of descent within the class Actinobacteria. Int. J. Syst. Evol. Microbiol. 53(Pt 2), 569-576. doi: 10.1099/ijs.0. 02400-0

Morillas, H., Maguregui, M., Marcaida, I., Trebolazabala, J., Salcedo, I., and Madariaga, J. M. (2015). Characterization of the main colonizer and biogenic pigments present in the red biofilm from La Galea Fortress sandstone by means of microscopic observations and Raman imaging. Microchem. J. 121, 48-55. doi: 10.1016/j.microc.2015.02.005

Musilova, M., Wright, G., Ward, J. M., and Dartnell, L. R. (2015). Isolation of radiation-resistant bacteria from Mars analog Antarctic Dry Valleys by preselection, and the correlation between radiation and desiccation resistance. Astrobiology 15, 1076-1090. doi: 10.1089/ast.2014.1278

Mykytczuk, N. C. S., Foote, S. J., Omelon, C. R., Southam, G., Greer, C. W., and Whyte, L. G. (2013). Bacterial growth at $-15^{\circ} \mathrm{C}$; molecular insights from the permafrost bacterium Planococcus halocryophilus Or1. ISME J. 7, 1211-1226. doi: 10.1038/ismej.2013.8

Newman, D. J. (2016). Predominately uncultured microbes as sources of bioactive agents. Front. Microbiol. 7:1832. doi: 10.3389/fmicb.2016.01832

Nichols, D., Cahoon, N., Trakhtenberg, E. M., Pham, L., Mehta, A., Belanger, A., et al. (2010). Use of ichip for high-throughput in situ cultivation of "uncultivable" microbial species. Appl. Environ. Microbiol. 76, 2445-2450. doi: 10.1128/AEM.01754-09

Nichols, D., Lewis, K., Orjala, J., Mo, S., Ortenberg, R., O’Connor, P., et al. (2008). Short peptide induces an "uncultivable" microorganism to grow in vitro. Appl. Environ. Microbiol. 74, 4889-4897. doi: 10.1128/AEM.00393-08

Paulino-Lima, I. G., Fujishima, K., Navarrete, J. U., Galante, D., Rodrigues, F., Azua-Bustos, A., et al. (2016). Extremely high UV-C radiation resistant microorganisms from desert environments with different manganese concentrations. J. Photochem. Photobiol. B Biol. 163, 327-336. doi: 10.1016/j.jphotobiol.2016.08.017

Pudasaini, S., Wilson, J., Ji, M., van Dorst, J., Snape, I., Palmer, A. S., et al. (2017). Microbial diversity of browning Peninsula, Eastern Antarctica revealed using molecular and cultivation methods. Front. Microbiol. 8:591. doi: 10.3389/fmicb. 2017.00591

Pulschen, A. A., Rodrigues, F., Duarte, R. T. D., Araujo, G. G., Santiago, I. F., Paulino-Lima, I. G., et al. (2015). UV-resistant yeasts isolated from a high-altitude volcanic area on the Atacama Desert as eukaryotic models for astrobiology. Microbiologyopen 4, 574-588. doi: 10.1002/mbo3.262

Quast, C., Pruesse, E., Yilmaz, P., Gerken, J., Schweer, T., Yarza, P., et al. (2013). The SILVA ribosomal RNA gene database project: improved data processing and web-based tools. Nucleic Acids Res. 41, D590-D596. doi: 10.1093/nar/ gks1219

Ragon, M., Fontaine, M. C., Moreira, D., and López-García, P. (2012). Different biogeographic patterns of prokaryotes and microbial eukaryotes in epilithic biofilms. Mol. Ecol. 21, 3852-3868. doi: 10.1111/j.1365-294X.2012. 05659.x

Rampelotto, P. H., Barboza, A. D. M., Pereira, A. B., Triplett, E. W., Schaefer, C. E. G. R., de Oliveira Camargo, F. A., et al. (2015). Distribution and interaction patterns of bacterial communities in an ornithogenic soil of Seymour Island. Antarctica. Microb. Ecol. 69, 684-694. doi: 10.1007/s00248-0140510-6

Reasoner, D. J., and Geldreich, E. E. (1985). A new medium for the enumeration and subculture of bacteria from potable water. Appl. Environ. Microbiol. 49, 1-7.

Rodrigues, D. F., and Tiedje, J. M. (2008). Coping with our cold planet. Appl. Environ. Microbiol. 74, 1677-1686. doi: 10.1128/AEM.02000-07

Rossi-Tamisier, M., Benamar, S., Raoult, D., and Fournier, P. (2015). Cautionary tale of using 16S rRNA gene sequence similarity values in identification of human-associated bacterial species. Int. J. Syst. Evol. Microbiol. 65, 1929-1934. doi: $10.1099 /$ ijs.0.000161

Rothschild, L. J., and Mancinelli, R. L. (2001). Life in extreme environments. Nature 409, 1092-1101. doi: 10.1038/35059215

Sait, M., Hugenholtz, P., and Janssen, P. H. (2002). Cultivation of globally distributed soil bacteria from phylogenetic lineages previously only detected in cultivation-independent surveys. Environ. Microbiol. 4, 654-666. doi: 10.1046/ j.1462-2920.2002.00352.x

Saito, T., Terato, H., and Yamamoto, O. (1994). Pigments of Rubrobacter radiotolerans. Arch. Microbiol. 162, 414-421.

Seki, T., Matsumoto, A., Shimada, R., Inahashi, Y., Omura, S., and Takahashi, Y. (2012). Conexibacter arvalis sp. nov., isolated from a cultivated field soil sample. Int. J. Syst. Evol. Microbiol. 62, 2400-2404. doi: 10.1099/ijs.0.036095-0

Skidmore, M. L., Foght, J. M., and Sharp, M. J. (2000). Microbial life beneath a high arctic glacier. Appl. Environ. Microbiol. 66, 3214-3220. doi: 10.1128/AEM.66.8. 3214-3220.2000

Stackebrandt, E., and Ebers, J. (2006). Taxonomic parameters revisited: tarnished gold standards. Microbiol. Today 33, 152-155.

Steven, B., Briggs, G., McKay, C. P., Pollard, W. H., Greer, C. W., and Whyte, L. G. (2007). Characterization of the microbial diversity in a permafrost sample from the Canadian high Arctic using culture-dependent and culture-independent 
methods. FEMS Microbiol. Ecol. 59, 513-523. doi: 10.1111/j.1574-6941.2006. 00247.x

Stewart, E. J. (2012). Growing unculturable bacteria. J. Bacteriol. 194, 4151-4160. doi: 10.1128/JB.00345-12

Tamaki, H., Hanada, S., Sekiguchi, Y., Tanaka, Y., and Kamagata, Y. (2009). Effect of gelling agent on colony formation in solid cultivation of microbial community in lake sediment. Environ. Microbiol. 11, 1827-1834. doi: 10.1111/j.1462-2920. 2009.01907.x

Tamura, K., Stecher, G., Peterson, D., Filipski, A., and Kumar, S. (2013). MEGA6: molecular evolutionary genetics analysis version 6.0. Mol. Biol. Evol. 30, 2725-2729. doi: 10.1093/molbev/mst197

Tanaka, T., Kawasaki, K., Daimon, S., Kitagawa, W., Yamamoto, K., Tamaki, H., et al. (2014). A hidden pitfall in the preparation of agar media undermines microorganism cultivability. Appl. Environ. Microbiol. 80, 7659-7666. doi: 10.1128/AEM.02741-14

Tang, H., Shi, X., Wang, X., Hao, H., Zhang, X.-M., and Zhang, L.-P. (2016). Environmental controls over actinobacteria communities in ecological sensitive Yanshan Mountains zone. Front. Microbiol. 7:343. doi: 10.3389/fmicb.2016. 00343

Tyson, G. W., Lo, I., Baker, B. J., Allen, E. E., Hugenholtz, P., and Banfield, J. F. (2005). Genome-directed isolation of the key nitrogen fixer Leptospirillum ferrodiazotrophum sp. nov. from an acidophilic microbial community. Appl. Environ. Microbiol. 71, 6319-6324. doi: 10.1128/AEM.71.10.6319-6324.2005

Vartoukian, S. R., Palmer, R. M., and Wade, W. G. (2010). Strategies for culture of "unculturable" bacteria. FEMS Microbiol. Lett. 309, 1-7. doi: 10.1111/j.15746968.2010.02000.x

Vester, J. K., Glaring, M. A., and Stougaard, P. (2013). Improving diversity in cultures of bacteria from an extreme environment. Can. J. Microbiol. 59, 581-586. doi: 10.1139/cjm-2013-0087
Wade, W. (2002). Unculturable bacteria-the uncharacterized organisms that cause oral infections. J. R. Soc. Med. 95, 81-83.

Wang, Y., Cai, F., Tang, Y., Dai, J., Qi, H., Rahman, E., et al. (2011). Flavitalea populi gen. nov., sp. nov., isolated from soil of a Euphrates poplar (Populus euphratica) forest. Int. J. Syst. Evol. Microbiol. 61, 1554-1560. doi: 10.1099/ijs.0.025221-0

Whitman, W. B., and Suzuki, K. (2015). “Solirubrobacterales," in Bergey's Manual of Systematics of Archaea and Bacteria, ed. W. B. Whitman (Chichester: John Wiley \& Sons), 1-3. doi: 10.1002/9781118960608.obm00025

Wojdyr, M. (2010). Fityk: a general-purpose peak fitting program. J. Appl. Crystallogr. 43, 1126-1128. doi: 10.1107/S0021889810030499

Wurch, L., Giannone, R. J., Belisle, B. S., Swift, C., Utturkar, S., Hettich, R. L., et al. (2016). Genomics-informed isolation and characterization of a symbiotic Nanoarchaeota system from a terrestrial geothermal environment. Nat. Commun. 7:12115. doi: 10.1038/ncomms 12115

Yoshida, S., Hiraga, K., Takehana, T., Taniguchi, I., Yamaji, H., Maeda, Y., et al. (2016). A bacterium that degrades and assimilates poly(ethylene terephthalate). Science 351, 1196-1199. doi: 10.1126/science.aad6359

Conflict of Interest Statement: The authors declare that the research was conducted in the absence of any commercial or financial relationships that could be construed as a potential conflict of interest.

Copyright (c) 2017 Pulschen, Bendia, Fricker, Pellizari, Galante and Rodrigues. This is an open-access article distributed under the terms of the Creative Commons Attribution License (CC BY). The use, distribution or reproduction in other forums is permitted, provided the original author(s) or licensor are credited and that the original publication in this journal is cited, in accordance with accepted academic practice. No use, distribution or reproduction is permitted which does not comply with these terms. 